\title{
Effect of Entrepreneurial Networks on Family Business Development: A Conceptual Consideration
}

\author{
Kenneth Chukwujioke Agbim ${ }^{1}$ \\ ${ }^{1}$ Business Administration Department, University of Agriculture, Makurdi, Nigeria \\ Correspondence: Kenneth Chukwujioke Agbim, Business Administration Department, University of Agriculture, \\ Makurdi, Nigeria, E-mail: kennethagbim2012@gmail.com
}

Received: June 1, 2018

Accepted: June 12, 2018

Online Published: July 21, 2018

\begin{abstract}
Family businesses are generally affected by resource constraints. These resource constraints are occasioned by the vagaries in the business environment. Consequently, budding and established family business entrepreneurs are now resorting to the acquisition and sharing of intangible resources as a strategy for achieving family business development. One type of resource that is increasingly being employed is entrepreneurial networks. In spite of the known supports entrepreneurial networks give to entrepreneurs at the different states of family business development, empirical evidences are still rear. Based on the foregoing, this study undertook a literature review and thereafter proposes that: the effect of family network on family business start-up is significant; the effect of intra-industry network on family business formalization is significant; the effect of professional network on family business professionalization is significant; the effect of extra-industry network on family business diversification is significant; the effect of social network on family business internationalization is significant; and the effect of intra-firm network on family business succession is significant. For family business development to be influenced by entrepreneurial networks, budding entrepreneurs, founder and/or descendant CEOs and employees of family businesses need to be actively involved in network relationships that encourage and facilitates resource acquisition and sharing. Moreover, an empirical study is recommended based on these propositions. This is to validate the propositions and to further add to the family business development and entrepreneurial networks literature.
\end{abstract}

Keywords: Entrepreneurship, Entrepreneurial networks, Family business, Family business development, Tipping points.

\section{Introduction}

Family businesses are generally affected by resource constraint. Resource constraint is one of the biggest trickle-down effects of the turbulence in today's business environment (Sirec \& Bradac, 2009; Onuoha, 2012; Ichrakie, 2013; Ottih, 2016). Business resources are the tangible and intangible resources that are owned and controlled by firms. Tangible resources have been made inadequate to support business development by business 
environmental vagaries (Teece, 2007; Ichrakie, 2013). This trend is gradually shifting the focus of firms to intangible resources. Entrepreneurial network is one of the intangible resources that make family businesses unique (Conner, 2007). In spite of the resource constraint, family businesses are still sources of employment opportunities, tax revenues to the government, business competition, innovation, creativity, foreign exchange, savings and gross domestic product (Onuoha, 2012). In addition, entrepreneurial networks are known to provide information, technologies, access to markets and other complementary resources for family businesses (Conner, 2007).

The oldest and most dominant type of business in the world is family business (Abouzaid, 2008; European Family Business, 2012). In family business, the owning family controls the capital, participate in the management of the company and have the will to transmit the company to the next generation (Bchini, 2014). Family business is also known as family firm, familial entrepreneurship and family entrepreneurship (Bratkovic, Antoncic \& Ruzzier, 2009; Zachary, Rogoff \& Phinisee, 2011). They can be habitual entrepreneurship (serial, portfolio) and can be found in all sectors of the economy (Heck, Hoy, Poutziouris \& Steier, 2008; Ogundele, Idris \& Ahmed-Ogundipe, 2012). Family businesses are of different sizes (micro, small, medium, large, multinational) and forms (sole proprietorship, partnership, joint venture, public limited company) (Qurashi, Hussain, Mushtaq \& Ullah, 2013). Families establish family businesses to create opportunities for their children, perpetuate family inheritance, hold the family together, give the families financial independence and inheritance (Ayranci, 2010). During the early part of industrialization, the resultant effect of the environment was market failure. As a reaction to the uncertainty and market failure, families became the interface between the market and the firm (Casson, 1999). Within this period, the business owners acquired the needed managerial knowledge and experience from families and communities rather than through training (Colli, 1998, 2003). The rise of modern corporations has shown that families lack the financial and human capital to sustain the development of family businesses in the capital and technology intensive industries (Chandler, 1990). However, growing evidence abound that Chandler undervalued the capabilities of family businesses (Sluyterman \& Winkelman, 1993). Areas were the capabilities of family businesses lie include the network of interrelated family businesses (Scranton, 1997), friendship and kinship ties (Colli, 2003). These capabilities have been employed by family businesses to increase their resilience in many sectors of the economy (Scranton, 1997).

Family business development is characterized by different entrepreneurial networks. Extant literature has shown that the most commonly used entrepreneurial networks are family, social, professional, intra-firm, intra-industry and extra-industry. Today, studies in business growth or development are witnessing a paradigm shift from stages of business development to tipping points. The identified tipping points in business literature are start-up, formalization, professionalization, diversification, internationalization and succession. However, studies on the effect of entrepreneurial networks on the tipping points in family business development are still rear. Thus, this study argues that entrepreneurial networks can affect the tipping points or states in family business development.

\section{Literature Review}

\subsection{Family Business}

Family business is "a small, medium-sized, large or multinational enterprise established or bought over through a solo or family (two or more individuals related by blood or marriage) entrepreneurial efforts and operated based on a high level of trust, commitment, familiness, involvement and control by the owning family and a somewhat fused ownership, management and/or governance systems with the founder, descendant or external CEO directing the achievement of the developmental and trans-generational visions of the family business" (Agbim, 2018a: 5: Agbim, 2018b: 3). 


\subsection{Entrepreneurial Networks}

Entrepreneurial networks are the relationships and ties entrepreneurs create and maintain with family members, friends, other entrepreneurs and organizations for the purpose of acquiring and sharing resources for either family or non-family business development. Sirec and Bradac (2009) opine that entrepreneurial networks can originate from internalization or externalization. Internalization suggests intensification of internal cooperation, while externalization connotes limited to outsourcing relationship. Entrepreneurial networks provide the entrepreneurs with support, exchanges and resources (tangible and intangible) that constitute strategic tools with which they pursue business development (Seerat, Ali \& Arif, 2011). However, "not all entrepreneurial networks are of equal value to the entrepreneur" (Bagwell, 2007: 379).

Moreover, networks can be formal or informal. Formal networks are intentionally formed groups of companies, generally operating in close proximity to each other. Informal networks consist of unintentional collection of organizations and individuals who have an interest in or links with the firm and/or its owner. Before the advent of the internet and social media, actors in a network interact on a face-to-face basis. Today, the internet and social networking platforms like Facebook have revolutionalized the activities of actors in a network. Entrepreneurial networks are continuously changing because they are not static with respect to entrepreneurial network type and the state of the business development in focus. This has necessitated first the use of one or a combination of any of family, intra-industry, professional, extra-industry, social and intra-firm entrepreneurial networks at the different states of business development. Second, the use of a combination of weak and strong ties in the pursuit of business development. Hamid (2013) asserts that the ties among family members are strong. Strong ties are reliable, but do not offer useful information like weak ties, while weak ties act as "bridges" to information sources not necessarily contained within an entrepreneur's strong tie.

\subsection{Tipping Points and Family Business Development}

Researchers have previously focused on the stages of business development when studying business growth or development (Mckelvie \& Wiklund, 2010). The results of such studies have raised more questions than answers. One of such key questions is: why is it that some firms grow and others do not? (Levie \& Lichtenstein, 2010; Hansen \& Hamilton, 2011). Other issues which have been raised concerning such studies are: there are no theories on the stages of business growth model; the questions that have been raised concerning the results of such studies have remained unanswered; and the stages of business growth model have not been validated empirically. Consequently, researchers conclude that the stages of business growth model have limitations (Leitch, Hill \& Neergaard, 2010; Levie \& Lichtenstein, 2010).

Some other researchers are of the view that the turbulence in today's business environment further contribute in rendering the stages of business growth model irrelevant. Current studies on business growth or development show that researchers now focus on tipping points or critical problem areas (Phelps, Adams \& Bessant, 2007; Omar, 2015). This suggests that they conceptualize firm growth through the notion of tipping points or critical problems rather than stages of growth. These researchers propose a shift from growth rate to growth mode (Mckelvie \& Wiklund, 2010) and from growth stages to growth states (Phelps et al., 2007).

The term "tipping points" is used to explain the critical incidents/problems faced by firms (Omar, 2015). Lamberson and Page (2012:2) define tipping points as "discontinuities in the relationship between parent conditions and future states of the system". Kekale and Helo (2014:2) assert that, "the central idea of the concept of tipping points is that in some phase of the development or evolution of a phenomenon, some small and apparently insignificant changes can turn up to have consequences out of proportion to themselves. The idea of tipping point assumes a gradually developing process, where every added incident is a decision point. A decision point where one added incident makes the development follow one of two or several strongly differing paths is 
the tipping point".

Tipping points result from change in the state or variable of interest and changes in the context surrounding that variable (Lamberson \& Page, 2012). Supporting Lamberson and Page's view, Phelps et al. (2007:8) notes that "tipping points are encountered during growth or are the consequence of environmental changes, and will depend on the specific context of the firm in its environment". Phelps et al. further notes that the managerial problems that formed the tipping points are people management, strategic orientation, formalization of systems, new market entry, finance, operational improvement and organizational knowledge.

Tipping points are the critical incidents that a firm face as it develops. These critical incidents occur due to environmental changes. Thus, family business development is the process of transitioning a solo or a group of family members entrepreneurially created (or bought) and/or managed family business through the critical incidents, problems or tipping points of start-up, formalization, professionalization, diversification, internationalization and/or intra and inter-organizational succession. This does not imply a sequential order of business development. This is because one family business can follow this order; another can even start as formalized, professionalized, diversified and/or internationalized firm.

\section{Proposition Development}

\subsection{Effect of Family Network on Family Business Start-up}

The start-up state in family business development is the time practical steps are taken to begin a business. At this state, the entrepreneur identifies business opportunities, draws a business plan and starts implementing the plan. Also, at this state, the entrepreneur is faced with challenges such as business funds, finding a suitable location for the new business, setting up business deals and agreements, hiring the right workers for the business, accessing information and acquiring skills. However, the most important challenge is initial capital (Anis \& Mohamed, 2012; Ottih, 2014).

The starting point of any business endeavour is the identification of business opportunities (Ozgen \& Baron, 2007). The ability of the entrepreneurs to identify opportunities with greater or lesser speed and intensity is influenced by the entrepreneurs' involvement in entrepreneurial networks. Opportunity identification or recognition is the process of perceiving a possibility to create a new business or to significantly improve the position of an existing business, and in both cases, new profit potential emerges (Anis \& Mohamed, 2012).

Some of the start-up resources come from the entrepreneurs, while others are obtained from the entrepreneur's contacts or external environment. The most important source of initial capital is personal sources, that is, the family. Thus, the entrepreneur needs family network to obtain his start-up capital. Subsequently, the need for the entrepreneur to be involved in intra-industry, professional, extra-industry, social and intra-firm networks will begin to emerge (Stewart \& Hitt, 2012; Abou-Moghli \& Al Muala, 2012; Bellavitis, Filatotchev \& Kamurimo, 2014).

Family network is the inter-relationship or interconnection among nuclear and extended family members for the purpose of accessing tangible and intangible resources. The nuclear and extended family members include some or all of grandfather, grandmother, father, mother, step father, step mother, brothers, sisters, step brothers, step sisters, nephews, nieces, cousins, uncles, aunties, and in-laws. These family members network electronically via the internet and traditionally during family meetings. Family networks can be created by birth, around sons and daughters. It can also be created by marriage, around wives and in-laws. Sons and daughters can build family network on secure and long-term basis. Family network created by marriage have characteristics that are different from other types of ties. Marriage creates a strong and long-lasting bond that binds family members together. Aside family network, marriage consolidate and reinforces friendship and other social ties. Marriage is one way of embedding a woman into her husband's family. 
Family network is formed by a group of people with a strong tie, kingship tie, an emotional closeness and a common past. The tie between this group of people, and within their family network is facilitated by the family norms, the trust mechanism, moral structure, information channels, collaborative dialogue and the family's point of view (Trevinyo-Ridriguez \& Bontis, 2010). The norm and trust are respectively useful in forming the family social capital and problems solving capability. The moral structure and information channels help to ensure a good relationship among family members in a family network and between the family members and the community, and to ensure that the family members participate in external organizations. The daily decisions of the family members are enhanced by collaborative dialogue, while the family's point of view awakens and provokes moral perception (Andrade et al., 2011).

Family network give entrepreneurs access to high quality and reliable information, knowledge and technology. For instance, when searching for business opportunities, entrepreneurs rely heavily on diverse networks (that lack ties between contacts) and weak ties. But when sourcing for start-up capital, entrepreneurs rely more on dense networks or strong ties because of the frequent contacts and emotional closeness. Omar (2015) found that personal networks (i.e., spouse, family, close relatives and close friends) are vital for both start-up and developing stages of business. The study carried out by Bagwell (2007) show that entrepreneurs rely heavily on strong family network ties for almost everything related to business operation and development. Based on the foregoing, it is proposed that:

Proposition 1: The effect of family network on family business start-up is significant.

\subsection{Effect of Intra-Industry Network on Family Business Formalization}

Family business formalization is the process of transitioning a family business from the informal to the formal sector through a change of form and orientation. Williams and Nadin (2012) opine that informal entrepreneurships or organizations are the organizations that participate in monetary transactions not declared to the State (government or its agency) for tax and/or benefit purposes when they should be declared but which are legal in all other respects. Many entrepreneurs carry on their businesses wholly or partially (Williams, 2006) in the large and growing informal sector all over the world (Charmes, 2009).

Formalization can be voluntary or involuntary. Voluntary formalization means graduating from the informal to the formal sector willingly without pressure from the relevant government enforcement agencies. Involuntary formalization is the abandonment of the informal sector (without conscious thought) to comply with the relevant laws governing the formal position as a result of coercion or compulsion from relevant government enforcement agencies. The result of the study carried out by Nelson and De Bruijn (2005) reveals that a good relationship among the founder/CEO (or successor), family members and employees enhances formalization. Intra-industry network is the tie, connection or relationship a firm has with other firms within the focal firm's industry (Stam \& Elfringe, 2008; Bellavitis et al., 2014). Intra-industry network provide cohesive environment, general behavioural rules, low risk and coordination costs, industry legitimacy, and reduced uncertainty regarding the firm's product or service quality (Coleman, 1988, as cited in Bellavitis et al., 2014). Hence, the proposition that: Proposition 2: The effect of intra-industry network on family business formalization is significant.

\subsection{Effect of Professional Network on Family Business Professionalization}

Professional network is the tie among employees of a firm who are members of similar professional association and who perform their duties based on the norms of the professional body. Greenwood, Suddaby and Hinings (2002) opine that the professional association plays a central role as carriers and promoters of desirable governance practices and organizing principles (Parada, Nordqvist \& Gimeno, 2010). These employees or professionals play a critical role in strategic decision-making in family firms (Chua, Chrisman \& Sharma, 2003) and in mentoring other employees to assist in playing professional roles (Amran \& Ahmad, 2010). Family 
business professionalization is a family business strategy of employing workers with specialized academic knowledge, membership of a professional body and who perform their task based on the professional norms of the professional body they belong to.

A family business is said to be professionalized when the family CEO is replaced by non-family CEO (Lin \& $\mathrm{Hu}$, 2007), functional structure and hierarchical governance are established and when professional norms and practices with well defined job positions and tax responsibilities are adopted (Hall \& Nordqvist, 2008). The results of the study conducted by Parada et al. show that families in professional associations change their values and consultants/family-business relationships. In addition, their interactions with other family businesses in the professional association enable them to share experiences and to receive tangible and intangible supports (Parada et al., 2010). Consequently, family business founder or descendant CEOs who wish to professionalize their firms can train family members to become professionals or employ professionals who will bring their professional norms and practices to bear on the firms' operations. Consequently, it is proposed that:

Proposition 3: The effect of professional network on family business professionalization is significant.

\subsection{Effect of Extra-Industry Network on Family Business Diversification}

Diversification is a family business group's way of extending their capabilities into new lines of business (Bru \& Crespi-Cladera, n.d.). A business group is a collection of legally independent firms that are connected by social ties (i.e., family, kinship and friendship) and economic links (i.e., ownership, financial and commercial) that leads to operational links (Guillen, 2005; Granovetter, 2005; Bru \& Crespi-Cladera, n.d.). During the diversification process, owner-managers of these companies stick to strategies that are compatible with maintaining socio-emotional wealth (Hernandez-Trasobares \& Galve-Gorriz, 2016). The owner-managers select the market and technology for the new business. It can be new or existing market; new or existing technology. The basis for the selection is usually the available resources and the acquired capabilities (Scur \& Queiroz, 2017). Family business diversification is the use of family business resources to start a new line of business.

Extra-industry network is "the relationship a firm maintains with firms that are established outside the focal firm's industry for the purpose of enhancing the identification of opportunities and acquisition of resources that are needed for diversification" (Agbim, 2018b: 3). Stam and Elfringe (2008) opine that extra-industry tie helps the focal firm to gain power and potential to identify opportunities, access diverse knowledge, heterogeneous and complementary resources that are not readily available within the focal firm's industry. Extra-industry network facilitate the learning of competencies and technologies, approaches, perspectives and idea that are not well established in the focal firm's industry (Hargadon, 2002). Ozkan-Canbolat (2014) found that organizations which are located relatively at the central part of the network and also have high level of ability to span structural holes take more risk to use diversification strategies. The results of the study conducted by Dries, Pascucci and Gardebroek (2012) shows that the relationship between a firm and other firms within and outside the focal firm's industry enhances diversification. Hence, the proposition that:

Proposition 4: The effect of extra-industry network on family business diversification is significant.

\subsection{Effect of Social Network on Family Business Internationalization}

Social network refers to the relationships among friends in a social club, social association or through social networking platform for mutual interest. These relationships facilitate resource sharing and exchange among participating actors (Agbim \& Eluka, 2018: 1). Before now, people get involved in social network to create and maintain relationship. However, recently, budding and established entrepreneurs and firms are getting involved in it because of the large market size it offers. Today, the emergence of the internet and the advances in information and communication technology has enhanced the interaction among actors in social network. The closeness of the relationships among the actors is now enhanced by the use of social networking platforms like 
Facebook. This closeness is measured on a scale that range from arm's length to social embeddedness. Arm's length relationship is characterized by lean and infrequent transactions; relationships started with special purposes and are limited to such purposes. Social embeddedness is the degree to which commercial transactions take place through social networks. Social embeddedness increase risk-taking and innovativeness inclinations in entrepreneurs, and reduces uncertainty through organizational co-ordination or mergers to show the usefulness of social network.

Social network help to identify opportunities and to access resources. Furthermore, social network supports venture creation and reduction in transaction costs - all the costs associated with the transfer of goods and services from one point to another. It enhances choice making with respect to foreign investment destination and internationalization (Seerat et al., 2011; Ogunnaike \& Kehinde, 2013). Family firms that are actively involved in social networks and advantageously positioned in the social web obtain resources and contacts that enhance business performance and promote internationalization process more quickly (Coutinho \& Moutinho, 2012).

Family business internationalization is the process of learning and accumulating knowledge on international business in preparation to getting involved in export, investment in a foreign business, starting a foreign subsidiary, or inclusion of expatriates in the top management of the family business. Chelliah, Pandian, Sulaiman \& Munusamy (2010) assert that international knowledge is knowledge in foreign ventures, foreign markets, information, multinational culture and the buyer behaviour in foreign market. International experience is referred to as the dealings with foreign business partners and the formation of co-operative agreements with foreign agents.

International knowledge and experience can be obtained by employing professionals with appropriate education and experience and from their networks. Thus, family businesses achieve internationalization faster when working in collaboration with others. This collaboration could take the form of exploitation of goods/services, shareholding by foreigners, inclusion of foreigners in the top management board and establishment of foreign subsidiaries (Chelliah et al., 2010; da Silva \& de Macedo-Soares, 2013; Pukall \& Calabro, 2014). Most firms start small and gradually internationalize, while others start as international firms. However, small firms have stronger tendency to internationalize than large firms. This is because small firms are looking for broader markets for their products/services (Chelliah et al., 2010). Zhou, Wu and Luo (2007) asserts that international business managers should consider social networks as efficient means of helping internally oriented SMEs to go international more rapidly and profitably. Seerat et al. (2011) found that small firms begin operations with the intent to internationalize and this intension is mainly enhanced once the entrepreneur discusses it with people whom he trusts most. Bello (2009) found that the capacity of SMEs to adjust to the requirements of the environments and to offer products adapted to the customers' needs at competitive prices is essential to their internationalization. Thus, the researcher proposes that:

Proposition 5: The effect of social network on family business internationalization is significant. 3.6 Effect of Intra-Firm Network on Family Business Succession

Succession is the process of ensuring that the management and/or ownership of a family business are transferred to competent family or non-family member (Mazzola et al., 2008; Bjornberg \& Nicholson, 2012; Lungeanu \& Ward, 2012). Family business leadership or management succession is the transfer of management position and responsibilities to a new family or non-family manager. Family business ownership succession is the transfer of family business ownership to a family member or to a third party.

In family business, male successors are perceived to be more supportive, tougher and more competitive than female successors. In relation to female successors, male successors have larger networks, get more supports from the family networks and perform better (Amran \& Ahmad, 2010). Female successors are more nurturing, 
more supportive in the work environment and focus more on achieving the objectives of the business than on financial performance (Butner \& Moore, 1997, as cited in Nwadukwe, 2012). These characteristics are influencing daughters and wives to rise in leadership positions in family businesses and to competitively participate in businesses initially/traditionally dominated by males (Nelton, 1998). Similarly, these characteristics are also responsible for the harmonious nature of the relationship between father and daughter. Daughters are less likely than sons to be in conflict with their fathers (Duman, 1992) over the transfer of the ownership or management of the family business.

However, it is important to note that the transfer of either ownership or management is done through succession planning (Luna, 2012). Succession planning helps to create the required talent pool of family members to meet future organizational needs (El-Chaarani, 2014). Owing to lack of succession planning, one-third of family businesses continue to the second generation and less than half of the second generation family enterprises make it to the third generation when the founder-manager retires or dies (Le Breton-Miller et al., 2004).

Succession planning demands that owner-managers train a member of the family to take over the business. The business owner states his or her successor in the succession plan. This document is important in the case of the sudden death of the founder/manager (Barach \& Granitsky, 1995). However, succession plan alone does not guarantee successful succession. Rather, knowledge has been identified as an important asset that must be combined with extensive succession plan to achieve higher performance. The business specific knowledge that must be created and transferred within the business enterprise is technical knowledge/skills (Ghingold \& Johnson, 1997).

It is very important for the successor to join the business as early as possible in order to gain experience, loyalty and emotional preparation through on-the-job training (El-Chaarani, 2014). This training is facilitated through intra-firm network. Intra-firm network is the relationship a business CEO has with others within the focal organization. Such a network is made up of employees from diverse units as well as diverse levels within the same organization (Collins \& Clark, 2003; Cao, Maruping \& Takeuchi, 2006). Family business intra-firm network therefore is the relationship or connection among all the family and non-family members who are working in the organizational units of the same family firm. Collins and Clark (2003) assert that a high level of embeddedness in the intra-firm network can maximize the CEOs ability to gather information from various parts and levels of the organization. The CEO through the intra-firm network in the firm can make effective evaluation and judgment on where the competencies lie in the organization, and where incremental improvement can be made (Liu \& Zhang, 2014).

Over time, the successor starts to share power with the current business leader and subsequently takeover the business from the founder (Pontent et al., 2007; Mazzola et al., 2008). Esuh et al. (2011) found that true succession will mediate the relationship between founder, successor and environment, and family business continuity. Gbadegeshin (2013) found that awareness of the family business owners, the attitude of the owners towards intra-succession as a means of business continuity is related to preparation for succession and business continuity. Memili (2015:423) states that "intra-family succession is critical for family firms' longevity". Through the performance/evaluation feedback, the successor is assessed by the owning family on the basis of passion for the job, managerial aptitude, empathic personality, vision for the future, and attitude towards the business and other workers (Le Breton-Miller et al., 2004; Fishman, 2009). The quality of the transfer is measured by the satisfaction of the stakeholders with the execution of the succession process (Sharma et al., 2003; Le Breton-Miller et al., 2004). Therefore, it is proposed that:

Proposition 6: The effect of intra-firm network on family business succession is significant. 


\section{Conclusion}

The study proposes that entrepreneurial networks (i.e., family, intra-industry, professional, extra-industry, social and intra-firm) exert influence on the tipping points of family business development (i.e., start-up, formalization, professionalization, diversification, internationalization and succession). For a family business to be influenced by these entrepreneurial networks, the founder and/or descendant CEOs and employees of the family business need to be actively involved in relationships that encourages and facilitates resource acquisition and sharing. Involvement in these relationships has become more important now than ever before owing to turbulence and uncertainty in today's business environment. Moreover, the unpredictability of business environmental factors has been linked to resource constraint, particularly intangible resources. Nevertheless, extant literature reveals that entrepreneurial networks are forms of intangible resources. An empirical study is recommended based on these propositions. This is to validate the propositions and to further add to the family business development and entrepreneurial networks literature.

\section{References}

Abou-Moghli, A. \& Al Muala, A. (2012). Impact of entrepreneurial networks in the success of business on-going stage in Jordanian manufacturing companies. American Academic \& Scholarly Research Journal, 4(2), 1-9.

Abouzaid, S. (2008). IFC family business governance handbook. Retrieved form http://www.ifc.org/wps/wcm/connect/15c9c0048582f6883f9ebfco46daa89/FB_English_final_200 8.pdf?Mod=AJPERES on October 21, 2016.

Agbim, K. C. \& Eluka, J. (2018). Social network and family business internationalization in South Eastern Nigeria. Journal of Accounting, Business and Finance Research, 3(2), 64-74. doi: 10.20448/2002.32.64.74

Agbim, K. C. (2018a). Business network effect on the institutionalization of family businesses in South Eastern Nigeria. Open Journal of Economics and Commerce, 1(1), 1-10.

Agbim, K. C. (2018b). Facilitating family business diversification through extra-industry network: Evidence from South Eastern Nigeria. Archives of Business Research, 6(7), 54-65. doi: 10.14738/abr.67.4844

Amran, N. A. \& Ahmad, A. C. (2010). Family succession and firm performance among Malaysian companies. International Journal of Business and Social Science, 1(2), 193-203.

Andrade, D. M., de Lima, J. B., Antonialli, L. M. \& de Muylder, C. F. (2011). The family social capital impact in practices of learning, change and innovation in entrepreneurial family businesses. African Journal of Business Management, 5(33), 12819-12828. doi: 10.5897/AJBM 11.1486

Anis, O. \& Mohamed, F. (2012). How entrepreneurs identify opportunities and access to external financing in Tunisian's microenterprises? African Journal of Business Management, 6(12), 4635-4647.

Ayranci, E. (2010). Family involvement in and institutionalization of family business: A research. Business and Economic Horizons, 3(3), 83-104.

Bagwell, S. (2007). Transnational family networks and ethnic minority business development: The case of Vietnamese nail-shops in the UK. International Entrepreneurial Behaviour \& Research, 14(6), 377-394. doi:10.1108/13552550810910960

Barach, J. A. \& Ganitsky, J. B. (1995). Successful succession in family business. Family Business Review, 8(2), 131-155.

Bchini, B. (2014). Entrepreneurship: A key to minimizing the risks of Tunisian family businesses. Journal of Business Studies Quarterly, 5(4), 68-80.

Bellavitis, C., Filatotchev, I. \& Kamuriwo, D. S. (2014). The effects of intra-industry and extra-industry 
networks on performance: A case of venture capital portfolio firms. Managerial and Decision Economics, 35(2), 129-144. doi: 10.1002/mde.2647

Bello, P. (2009). Internationalization of Cameroonian small and middle enterprises (SMEs): Myth or reality? African Journal of Business Management, 3(2), 052-069.

Bjornberg, A. \& Nicholson, N. (2012). Emotional ownership: The next generation's relationship with family firm. Family Business Review, 25(4), 374-390.

Bratkovic, T., Antoncic, B. \& Ruzzier, M. (2009). The personal network of the owner-manager of a small family firm: The crucial role of the spouse. Managing Global Transition, 7(2), 171-190.

Bru, L. \& Crespi-Cladera, R. (n.d.). Diversification of family business groups (FGG) and board control. Universita de les Balears, Campus Crade Valldemossa, Palma de Mallorca.

Cao, Q., Maruping, L.M. \& Takeuchi, R. (2006). Disentangling the effects of CEO turnover and succession on organizational capabilities: A social network perspective. Organization Science, 17, 563-576.

Casson, M. (1999). The economics of the family firm. Scandinavian Economic History Review, 47(1), 10-23.

Chandler, A. D. (1990). Scale and scope. Cambridge, Mass.: Harvard University Press.

Charmes, J. (2009). Concepts, measurement and trends, In J. P. Jutting \& J. R. Laiglessia (Eds.), Is informal normal? Towards more and better jobs in developing countries (Pp19-35). Paris: OECD.

Chelliah, S., Pandian, S., Sulaiman, M. \& Munusamy, J. (2010). The moderating effect of firm size: Internationalization of small and medium enterprises (SMEs) in the manufacturing sector. African Journal of business Management, 4(14), 3096-3109.

Chua, J. H., Chrisman, J. J., \& Sharma, P. (2003). Succession and non-succession concerns of family firms and agency relationship with non-family managers. Family Business Review, 16(2), 89-108.

Colli, A. (1998). Networking the market: Evidence and conjectures from the history of the Italian industrial districts. European Year Book of History, 1, 75-92.

Colli, A. (2003). The history of family business, 1850-2000. Cambridge: Cambridge University Press.

Collins, C. J. \& Clark, K. (2003). Strategic human resource practices, Top management team social networks, and firm performance: The role of human resource practices in creating organizational competitive advantage. Academy of Management Journal, 46, 740-751.

Conner, T. (2007). Research notes and commentaries, market orientation and performance. Strategic Management Journal, 28, 957-959.

Coutinho, R. J. F. \& Moutinho, R. M. (2012). Generational succession as a trigger for family business internationalization. Economics and Management Research Projects, 2(1), 1-17.

da Silva, G. F. \& de Macedo-Soares, T. D. (2013). The role of international alliance networks and their impact on firms' internationalization process. Bento Gonzalves, 19(21), 1-16.

Dries, L., Pascucci, S \& Gardebroek, C. (2012). Diversification in Italian farm systems: Are farmers using interlinked strategies? New Medit N, 4, 7-15.

Duman, R. (1992). Family firms are different. Entrepreneurship Theory and Practice, 17, 13-21.

El-Chaarani, H. (2014). The success keys for family firms: Comparison between Lebanese and French systems. Lebanese Science Journal, 15(2), 133-150.

Esuh, O. L., Mohd, S. M. \& Adebayo, O. I. (2011). A Conceptual framework of family business succession: Bane of family business continuity. International Journal of Business and Social Science, 2(18), 106-113.

European Family Business (2012, June). Family business. Retrieved from http:/www.europeanfamilybusiness.eu/uploads/modules/publications/family-business-statistics.pdf on 
March 21, 2016.

Fishman, A. (2009, December 13). When business is kept in the family. Sunday Times Newspaper, p.2.

Gbadegeshin, S. A. (2013). Awareness of "ownership succession" and family business continuity. International Journal of Business and Management Invention, 2(9), 72-87.

Ghingold, M. \& Johnson, B. (1997). Value added in business markets: Implications for procurement and marketing. Industrial Marking Management, 26, 271-280.

Granovetter, M. (2005). Business groups and social organization, In N. J. Smelsen \& R. Swedberg (Eds.), The hand book of economic sociology. Princeton: Princeton University Press.

Greenwood, R., Suddaby, R., \& Hinings, C. R. (2002). Theorizing change: The role of professional associations in the transformation of institutionalized fields. Academy of Management Journal, 45, 58-80.

Guillen, M. F. (2005). The rise of Spanish multinationals. New York: Cambridge University Press.

Hall, A. \& Nordqvist, M. (2008). Professional management in family businesses: Toward an extended understanding. Family Business Review, 21(1), 51-69.

Hamid, N. F. B. A. (2013). Family business culture, entrepreneurial orientation and the new economic policy on family business survival: A study between the Malays and Chinese of micro and small-sized family business in Malaysia (Unpublished Ph.d thesis). The University of York, York.

Hansen, B. \& Hamilton, R. T. (2011). Factors distinguishing small firm growers and non-growers. International Small Business Journal, 29, 278-294.

Hargadon, A. (2002). Brockering knowledge: Linking learning and innovation, In B. M. Staw \& R. M. Kramer (Eds.), Research in organizational behaviour (Vol. 24:41-85). Greenwich, CT: JAI Press.

Heck, R. Z., Hoy, F., Poutziouris, P. Z. \& Steier, L. P. (2008). Emerging paths of family entrepreneurship research. Journal of Small Business Management, 25(3), 317-330.

Hernandez-Trasobares, A. \& Galve-Gorriz, C. (2016). Diversification and family control as determinants of performance: A study of listed business groups. European Research in Management and Business Economics, 23, 46-54. doi: 10.1016/j.iedeen.2016.04.001

Ichraikie, F. (2013). Intangible resources as key determinants of job network providers' success: A resource-based study. Australian Journal of Business and Management Research, 2(11), 43-63.

Kekale, T. \& Helo, P. (2014). The tipping points of technology development. Quality Innovation Prosperity, XVIII(1), 1-14. doi: 10.12776/QIP. V1811.211

Lamberson, P. J. \& Page, S. E. (2012). Tipping points. SFI working paper 2012-02-002. Santa Fe Institute.

Le Breton-Miller, I., Miller, D. \& Steier, L. P. (2004). Toward an integrative model of effective FOB succession. Entrepreneurship Theory and Practice, 28(4), 305-328.

Leitch, C., Hill, F. \& Neergaard, H. (2010). Entrepreneurial and business growth and the quest for a “compressive theory": Tilting at windmills? Entrepreneurship Theory \& Practice, 34, 249-260.

Levie, J. \& Lichtenstein, B. B. (2010). A terminal assessment of stages theory: Introducing a dynamic states approach to entrepreneurship. Entrepreneurship Theory \& Practice, 34, 317-350.

Lin, S. \& Hu, S. (2007). A family member or professional management? The choice of CEO and its impact on performance. Corporate: An International Review, 15(6), 1348-1362.

Liu, N \& Zhang, H (2014). The role of CEOs intra-frim network in innovation orientation of hi-tech entrepreneurial firms. Biotechnology: An Indian Journal, 10(22), 14014-14020.

Luna, G. (2012). Planning for an American higher education leadership crisis: The sucession issue for administrators. International Leadership Journal, 4(1) 56-79.

Lungeanu, R. \& Ward, J. L. (2012). A governance-based typology of family foundations: The effect of 
generation stage and governance structure on family philanthropic activities. Family Business Review, 25(4), 409-424.

Mazzola, P., Machisio, G. \& Astrachan, J. (2008). Strategic planning in family business: A powerful developmental tool for the next generation. Family Business Review, 21(3), 239-258.

Mckelvie, A. \& Wiklund, J. (2010). Advancing firm growth research: A focus on growth model instead of growth rate. Entrepreneurship Theory \& Practice, 34, 261-288.

Memili, E. (2015). Performance and behaviour of family firms. International Journal of Financial Studies, 3, 423-430. doi:10.3390/ijfs3030423

Nelson, E. \& De Bruijn, E. (2005). The voluntary formalization of enterprises in a developing economy: The case of Tanzania. Journal of International Development, 17(4), 575-593.

Nelton, S. (1998). Social network analysis as an intervention tool: Examples from the field. Group Organization Studies, 13, 39-59.

Nwadukwe, U. C. (2012). The effect of Igbo inheritance culture on management succession in private indigenous enterprises in south eastern Nigeria (Unpublished Ph.d thesis). University of Nigeria, Enugu Campus, Enugu.

Ogundele, O. J. K., Idris, A. A. \& Ahmed-Ogundipe, K. A (2012). Entrepreneurial succession problems in Nigeria's family businesses: A threat to sustainability. European Scientific Journal, 8(7), 208-227.

Ogunnaike, O. O. \& Kehinde, O. J. (2013). Social networking and business performance: The case of selected entrepreneurs in Ota, Nigeria. Journal of Business and Management Sciences Research, 2(5), 116-122.

Omar, S. S. (2015). The entrepreneurial network of Muslim women entrepreneurs: The study of multiple-cases of small businesses in the southern region of Malaysia. Paper presented at the $2^{\text {nd }}$ AFAP International Conference on Entrepreneurship and Business Management, Universiti Tecknologi Malaysia, Kuala Lumpur, Malaysia, January 10-11.

Onuoha, B. C. (2012). Professionalizing family business in the South-East Region of Nigeria. International Business and Management, 5(1), 153-161. doi:10.3968/j.ibm.1923 842820120501.1075

Ottih, L. O. (2014). Entrepreneurship: Personality, process and enterprise. Port Harcourt: Pearl.

Ottih, L. O. (2016). Strategic management: Text and cases. Port Harcourt: Pearl.

Ozgen, E. \& Baron, R. A. (2007). Social sources of information in opportunity recognition: Effects of mentors, industry networks and professional forums. Journal of Business Venturing, 22, 174-192.

Ozkan-Canbolat, E. (2014). Organizational network effect on diversification strategies. Strategic Management Quarterly, 2(2), 27-48.

Parada, M. J., Nordqvist, M. \& Gimeno, A. (2010). Institutionalizing the family business: The role of professional associations in fostering a change of values. Family Business Review, 26, 1-18.

Phelps, R., Adams, R. \& Bessant, J. (2007). Life cycles of growing organizations: A review with implications for knowledge and learning. International Journal of Management Review, 9(1), 1-30.

Pontent, S., Worsch, C. \& Gagne, M. (2007). An exploration of the generational differences in levels of control held among family businesses approaching succession. Family Business Review, 20(4), 337-354.

Pukall, T. J. \& Calabro, A. (2014). The internationalization of family firms: Critical review and integrative model. Family Business Review, 27(2), 103-125. doi:10.1177/08944866513491423

Qurashi, A., Hussain, I., Mushtaq, F. \& Ullah, A. (2013). The dilemma of success and failure in family business: Overcoming failure and attaining success. International Journal of Academic Research in Economics and Management, 2(4), 161-177. doi:10.6007/IJAREMS/v2-i4/121

Scranton, P. (1997). Endless novelty: Specialty production and American industrialization, 1865-1925. 
Princeton: Princeton University Press.

Scur, G. \& de Queiroz, R. P. (2017). The impact of diversification in the operations of strategy of capital goods companies. Gest. Prod., Sao Carlos, 24(2), 206-220. doi: 10.159010104-530x1048-13

Seerat, F., Ali, M. \& Arif, S. (2011). Network classification on the basic of functions they perform and its relationship with internationalization process of SMEs in developing countries - Exploratory research on Pakistan. Australian Journal of Business and Management Research, 1 (8), 35-53.

Sharma, P., Chrisman, J.J. \& Chua, J.H. (2003). Predictors of satisfaction with the succession process in family firms. Journal of Business Venturing, 18(5), 667-687.

Sirec, K. \& Bradac, B. (2009). How does networking impact the SMEs growth. Organizacija, 42 (2), 59-66. doi: 10.2478/V10051-0051-009-0003-4

Sluyterman, K. E. \& Winkelman, H. J. M. (1993). The Dutch family firm confronted with Chandler's dynamics of industrial capitalism, 1890-1940. Business History, 35(4), 152-183.

Stam, W. \& Elfring, T. (2008). Entrepreneurial orientation and new venture performance: The moderating role of intra- and extra industry social capital. Academy of Management Journal, 51(1), 97-111.

Stewart, A. \& Hitt, M. (2012). Why can't a family business be more like a non-family business? Modes of professionalization in family firms. Family Business Review, 25(1), 58-86.

Teece, D. (2007). Explicating dynamic capabilities: The nature and micro foundations of (sustainable) enterprise performance. Strategic Management Journal, 28, 1319-1350.

Trevinyo-Rodriguez, R. N. \& Bontis, N. (2010). Family ties and emotions: A missing piece in the knowledge transfer puzzle. Journal of Small Business and Enterprise Development, 17(3), 418-436.

Williams, C. C. \& Nadin, S. (2012). Tackling entrepreneurship in the informal economy: Evaluating the policy options. Journal of Entrepreneurship and Public Policy, 1(2), 111-124.

Zachary, R. K., Rogoff, E. G. \& Phinisee, I. (2011). Defining and identifying family entrepreneurship: A new view of entrepreneurs, In M. Minnitti (Ed.), The dynamics of entrepreneurship: Evidence from the Global Entrepreneurship Monitor data (pp. 57-76). New York: Oxford University Press.

Zhou, L., Wu, W. \& Luo, X. (2007). Internationalization and the performance of born-global SMEs: The mediating role of social networks. Journal of International Business Studies, 38, 673-690. doi: 10.1057/palgrave.jibs.8400282

\section{Copyrights}

Copyright for this article is retained by the author(s), with first publication rights granted to the journal.

This is an open-access article distributed under the terms and conditions of the Creative Commons Attribution license (http://creativecommons.org/licenses/by/4.0/). 